\title{
Standing Committees' Responses in Promoting Peace, Justice and Strong Institution (SDG 16) at Local Level in Bangladesh
}

\author{
A K M Mahmudul Haque ${ }^{1 *}$, Md. Asfaq Salehin², Jannatul Ferdous ${ }^{3}$, Md. Masum Billah ${ }^{4}$, Syed Mohammad Aminur \\ Rahman $^{5}$ \\ ${ }^{1}$ Department of Political Science, University of Rajshahi, Rajshahi 6205, Bangladesh \\ ${ }^{2}$ Institute of Bangladesh Studies, University of Rajshahi, Rajshahi 6205, Bangladesh \\ ${ }^{3}$ International Management (Applied), Teesside University, Middlesbrough TS1 3BX, United Kingdom \\ ${ }^{4}$ Applied International Development, University of Reading, Berkshire, Reading, RG6 6EU, United Kingdom \\ ${ }^{5}$ Department of Geography, Environment and Population, University of Adelaide, Adelaide SA 5005, Australia
}

Corresponding Author Email: akmmahmudul@ru.ac.bd

https://doi.org/10.18280/ijsdp.160502

Received: 8 July 2021

Accepted: 10 September 2021

\section{Keywords:}

local government, peace and justice. standing committee, sustainable development goals, union parishad

\begin{abstract}
Sustainable development goals have incorporated all the aspects of our society. The proper achievement of these goals can be the redemption for the third world countries in terms of politics, society and economy. Goal 16 is introduced in order to promote peace and ensure an inclusive society. The targets and indicators of this goal more or less focus on ensuring effective, accountable and transparent institutes which conceal flexible, inclusive, participatory and representative decision making. On the other hand, the committee system of our local government has been designed exactly to pursue the same objectives as goal no 16. This study was conducted on three Union Parishads (Union Councils) of Rajshahi district and interviewed all the presiding members of Standing Committees. The study also considered the awareness of local residents in the question of activation and effectiveness of the standing committees. It used mostly qualitative data and the direct opinions of the respondents. A few quantitative data have been included as well. The study found our local representatives totally clueless about their committees and Union Parishads totally devoid of the committee practice. This study suspects that our local bodies will hardly be able to contribute anything at all to promoting peace, justice and strong institution.
\end{abstract}

\section{INTRODUCTION}

Sustainable Development Goals (SDGs) is now a talked issue in the world. Since MDG was a success, the United Nations dared to show ambition for SDGs. Countries like Bangladesh who are desperate to transform as a nation with middle income instantly reacted to pursue the goals. There are 17 goals, which encompass all the socio-economic aspects of a society [1]. Among them, goal 16 is dedicated to promote peaceful and inclusive societies for sustainable development, provide access to justice for all and build effective, accountable and inclusive institutions at all levels. Goal 16 which is manifested to ensure peace, justice and strong institutions is undeniable to achieve all the other goals of SDG. Focusing on human rights, rule of law, end of inequality and most importantly ensuring good governance is the key focus of this venture [2]. It is true that achieving SDGs is certainly a mammoth task for any country of the world. Bangladesh is no exception to that. It has highly prepared itself to emerge toward success. Bangladesh Bureau of Statistics in this context has claimed, if five key challenges such as data management, capacity development, policy integration and reform, structural and institutional reform, and resource mobilization are dealt successfully then all 17 goals are achievable [3]. Considering the promises and drawbacks, the government has already traced out five major limitations to be overcome.
These are as Data Management, Capacity Development, Policy Integration and Reform, Structural and Institutional Reform, and Resource Mobilization [3].

Therefore, the role of our local government is undoubtedly crucial in this journey. Numbers of plans and strategies have been developed incorporating the local government authorities of Bangladesh. Union Parishad (UP) is the lowest rural-local government body. Each Union is made up of nine Wards. It is governed by an elected council which consists of a Chairman and twelve members including three members exclusively reserved for women. In Bangladesh, more than $60 \%$ people are still residing at Union Parishad. Therefore, Union Parishads have a groundbreaking role to play in this regard. The Seventh Five Year Plan of the government of Bangladesh comprised the local government as the key stakeholder in this venture [4]. The Standing Committees (SC) of Union Parishad are such unique tools that have the power to work with every local affair intimately without being influenced by the formal law. Therefore, it can be highly efficient in concealing inclusion, good governance and strengthening the local institutions [5].

In order to discharge the functions of local government accordingly and to ensure participation of the local people, every UP must form 13 or more SCs including 5-7 members, dedicated to different sectors, such as, finance and establishment, audit and accounts, taxation and collection, education, health, family planning and epidemic control, 
agriculture, fisheries, livestock and other development works, rural infrastructural development, protection and preservation, law and order, birth and death register, rural water supply and sanitation, social welfare and disaster management, conservation of environment and tree plantation, women and children welfare and resolving family conflict, and culture and sports [6]. Their key functions are to look after all the social affairs intimately and to correspond with the local people about all the affairs. The committees have the authority to discuss any crisis or programs and to recommend the Parishad to take necessary steps on concerned issues. On the other hand, all the local authorities who are entrusted with the responsibilities to work locally must give their feedback to the concerned SC. SCs also offers a great opportunity to the residents to become a cooperative member and participate in all the meetings held once every two months. As the committees are not bound to obey any formal law, they can discuss anything and submit the report to the Parishad. By conducting these functions as directed by the Local Government (Union Parishad) Act 2009, the SCs can ensure participation and make the local body more inclusive than ever. These committees can also increase accountability and ensure good governance of the local institutions.

Conducting as per the Local Government (Union Parishad) Act 2009, the SCs of Union Parishads will eventually be one of the most dominant actors to ensure peace, justice and strong institutions. Peace is something which includes success, fulfillment, harmony, wholeness, security and wellbeing should be present in any state [7]. On the other hand, among multiple explanations of justice, Union Parishads being just at governing inside their jurisdiction and ensuring inclusiveness and equality among the citizens of their Parishad, have been considered in this paper. In this regard, this paper had an attempt to identify standing committees of Union Parishad as an institution which have potential to offer peace and justice among the citizens of Union Parishad. After analyzing the current functionality and the existing practice of governing tools of the UPs along with the goals and objectives of SDG 16 and SDG driven national guidelines to the local government of Bangladesh, this paper argues that if Union Parishads are to be considered as strong institutions offering peace, justice, it must have its standing committees functional. This study tries to figure out the potentials of SCs as one of the key actors for our nations' sustainable development to promote peace and justice at the grassroots level and ensuring inclusiveness and strengthening respective institutions through maintaining good governance.

\section{METHODOLOGY}

This study is an empirical research where qualitative research strategy was employed supplemented by appropriate quantitative method. Primary data have been collected by interviewing 39 (13X3) members of $13 \mathrm{SCs}$ and three elected representatives of three selected Union Parishads. So a total of 42 respondents have been interviewed using a questionnaire including both open ended and close ended questions. For secondary data, this study used newspaper articles, books, Union Parishad Manual and mostly online publications. The study also incorporated data and evidence from the government portals.

The study has been carried out in three Union Parishads of Rajshahi district from three different Upazilas (Sub-districts). The selected Union Parishads are, Yusufpur from Charghat Upazila, Godagari Sadar from Godagari Upazila, and Puthia from Puthia Upazila. Each location was chosen considering the area, age and remoteness from the divisional district. The infrastructural conditions of the Union Parishads were also considered in finalizing the study area.

\section{RESULTS AND DISCUSSION}

There can be no disagreement to this statement that SCs of Union Parishad have been proved as one of the crucial stakeholders in achieving SDG 16. Therefore, the prospect of $\mathrm{SC}$ is boundless. However, the practice of SC is so lousy that any trace of their function can hardly be found. Different researches have been conducted by the scholars overtime and the result was the same. Simulation program was run in selected regions but the result was not satisfactory. As a part of the research, Ilias and Islam simulated SC meeting in UPs. They made the UP members sit on SC meetings on a regular basis. But during the simulation, they found in three of the studied seven UPs that SCs are not even formed properly. By the way he saw eagerness among the members of Union Parishad to sit in the meeting and respond spontaneously. However, the Union Parishad members showed demand, which was not common but very personal. For these various reasons, he found the SC meetings are hardly effective and felt the urge of activating these [8].

In this research, the result was hardly found different while the survey was conducted in three UPs of Rajshahi such as, Yusufpur, Puthia, and Godagari. In fact, the situation is even worse now. The formation and structure of the committee was primarily focused. During the survey, it was figured out whether the committees are properly formed or not.

During the survey, it was found that in 2 UPs among 3, all the SCs were not even formed (Table 1). In Yusufpur, all 13 committees were formed at the first meeting of UP which was good but irregularity was noticed in the formation. When the UP was asked to give their list of committees and members it was found that, only $40(61.53 \%)$ members' contact details were available among 65 which raises questions over committee's functionality.

Table 1. Standing committees of three union parishads

\begin{tabular}{ccccccc}
\hline \multirow{2}{*}{ Name of the Union } & \multicolumn{2}{c}{ Formed } & \multicolumn{2}{c}{ Faulty } & \multicolumn{2}{c}{ Devoid } \\
& Number & Rate & Number & Rate & Number & Rate \\
\hline Yusufpur & 5 & $38.46 \%$ & 8 & $61.31 \%$ & 0 & $0 \%$ \\
Puthia & 6 & $46.15 \%$ & 0 & $0 \%$ & 7 & $53.84 \%$ \\
Godagari & 6 & $46.15 \%$ & 0 & $0 \%$ & 7 & $53.84 \%$ \\
Total & 17 & $43.58 \%$ & 8 & $20.52 \%$ & 14 & $35.90 \%$ \\
\hline
\end{tabular}

Source: Field Survey 2019 [9] 
The scenery of Puthia and Godagari are even worse. In Puthia, only $6(46.15 \%)$ out of 13 committees was existed and the rest of the $7(53.84 \%)$ committees were not even formed. When their secretary was asked to give the list of the SCs formed, he instantly formed the rest of the 7 committees. The situation of Godagari Union Parishad is not any better. They are also devoid of 7 committees. According to one of the personnel of Godagari Union, the committees were formed during the training of the UP members under Efficient and Accountable Local Government (EALG) project. Table 2 shows more details about the existence of each committee.

Panday has described the emergence of SC elegantly. He has pointed out how efficient and potential the SC can be in the question of ensuring proper participation at the grassroots level in policy making [10]. He also proved how SC can maintain the democratic practice without taking anything from the executive. In his word,

"The maximum use of SC has emerged as one of the important ways of strengthening democratic institutions without weakening the executive."

But the unfortunate thing according to Panday is that, those SCs at UP level often form but fail to perform currently. The malfunction of these committees often leads to very depressing results. SCs often fail to ensure proper accountability of the governing process of UPs [10]. As a reason behind the failure of those committees, he pointed out,

"One of the notable causes of lack of effectiveness is that members of these committees lack an adequate level of understanding about the Terms of References (ToRs) of their committees."

"There are instances that many ward members who are also the members and chair of different committees lack understanding about the main purpose of these SCs. Even, many of them are found ignorant about the name of the committees they are affiliated with."

There is hardly any progress in the aspect of implementation of the decisions they usually take in those meetings. However, in terms of the frequency of meeting, none of the SCs were found regular though according to the UP Manual, each of the 13 SCs is supposed to sit once in every two months [10].

Hossain has found the UP's jurisdiction is very narrow and their functions are very limited [11]. Even if they want to remain functional in the responsibilities they are entrusted with by the government, they often have to encounter the limitation of budget and insufficient manpower. As a result, the outcome is never satisfactory.

In the term of co-opt members of the SC of the UP, the situations never gets any better. SCs are constituted with 5-7 members along with the co-opt members. Hossain claimed that the co-opt members should have the voting rights. In his article, he mostly focused on the efficiency of the SC in terms of being more accountable [11]. However, very little is known from his study about how much we really perceive. The benefits which are mentioned by him are true but it depends on the successful practices of SC. Findings of these literature are completely reflected in the findings of the survey (Table 2) which clarifies the overall situation of SCs of Union Parishad. According to the field data, it seems like the situation cannot be worse than this. Nothing about the SCs of Union Parishad is in order, from the training to infrastructure, from awareness to practice, literally every single component of the SCs is out of function. Members including the presiding ones are found completely ignorant in this context.

Table 2. Overall situations of standing committees

\begin{tabular}{|c|c|c|c|c|c|c|}
\hline & verall Situation of Standing Committee & Yusufpur & Puthia & Godagari & Total & Status \\
\hline \multicolumn{7}{|c|}{ Formation and Meeting } \\
\hline 1. & Committee formation & Properly & No & No & $48.58 \%$ & Half \\
\hline 2. & Existence of extra committee other than 13 & No & No & No & $0 \%$ & None \\
\hline 3. & Urgency of forming one & No & No & No & $0 \%$ & None \\
\hline 4. & Any specialist member in the committee & Yes & Yes & Yes & $\mathrm{n} / \mathrm{a}$ & Undefined \\
\hline 5. & Meeting & Never & Never & Never & $0 \%$ & Never \\
\hline 6. & Total number of meeting so far & Null & Null & Null & $0 \%$ & None \\
\hline \multicolumn{7}{|c|}{ Awareness of the Committee Chairmen } \\
\hline 7. & Awareness of the committee they own & $30.77 \%$ & $15.39 \%$ & $69.23 \%$ & $38.46 \%$ & A few \\
\hline 8. & Aware of the functions of the committee & $46.15 \%$ & $7.70 \%$ & $100 \%$ & $51.28 \%$ & Half \\
\hline 9. & Awareness of the committee affair & No & No & No & $0 \%$ & None \\
\hline 10. & Familiar with the legal provision of SC & No & No & No & $0 \%$ & None \\
\hline \multicolumn{7}{|c|}{ Functionality and Effectiveness } \\
\hline 11. & Meeting period & Never & Never & Never & $\mathrm{n} / \mathrm{a}$ & None \\
\hline 12. & Total number of meeting & Null & Null & Null & $0 \%$ & None \\
\hline 13. & Exhortation of Chairman and Secretaries & No & Yes & No & $\mathrm{n} / \mathrm{a}$ & No \\
\hline 14. & Local people's exhortation & No & No & No & $\mathrm{n} / \mathrm{a}$ & None \\
\hline 15. & Discussion of related affair in the meeting & Never & Never & Never & $\mathrm{n} / \mathrm{a}$ & None \\
\hline 16. & Reporting the UP in black and white & Never & Never & Never & $\mathrm{n} / \mathrm{a}$ & None \\
\hline 17. & Co-ordination with other service providers & Yes & Yes & Yes & $\mathrm{n} / \mathrm{a}$ & None \\
\hline 18. & Corresponding through committee & No & No & No & $\mathrm{n} / \mathrm{a}$ & None \\
\hline 19. & Assisting the local service providers & No & No & No & $\mathrm{n} / \mathrm{a}$ & None \\
\hline 20. & Supervising schemes and projects as SC & No & No & No & $\mathrm{n} / \mathrm{a}$ & None \\
\hline 21. & Articulating local resident's demand & No & No & No & $\mathrm{n} / \mathrm{a}$ & None \\
\hline 22. & Influencing the UP to take decision & No & No & No & $\mathrm{n} / \mathrm{a}$ & None \\
\hline 23. & Special discussion over plans and projects & No & No & No & $\mathrm{n} / \mathrm{a}$ & None \\
\hline 24. & Effectiveness & No & No & No & $\mathrm{n} / \mathrm{a}$ & None \\
\hline
\end{tabular}


Table 2 clearly depicts the trouble of SCs. Speaking of formation and meeting, only one out of three Union Parishads has been able to provide a complete structure of SCs during field survey. In the case of Puthia, they only provided the formation of six committees during the data collection. So, did the Godagari. After the interview, the Secretaries of both of the Unions cared to send the researchers a complete document with the list of members in 13 committees. However, there was no contact detail of the committees. Only $51.28 \%$ of the members of the Union Parishads were aware about the functions of SC.

Since the law bound committees are not properly formed, it will be highly ambitious to expect the existence of extra SC as well as the urgency to form one. When the presiding members of the SCs were asked about the frequency of meeting, they responded irrationally. Even though a few of them said that they sit in meeting in a regular basis, some of them confessed that there were no meetings. Further enquiry revealed the truth later that there was no meeting at all. However, no evidence was provided to support their claim. Moreover, in the question of number of meeting, each of the selected Unions failed to provide any written record of meetings. During the interview, a very unfortunate thing was discovered. Some of the members completely mixed the idea of SC meeting with the idea of Ward Shava, which highly indicates the level of ignorance of the SC members. On the other hand, according to Table 2, only $38.46 \%$ presiding members of the committee were found aware about the idea of SC and only $51.28 \%$ of the presiding members are familiar with the functions of SCs to some extent.

Therefore, the functionality and effectiveness of the SCs can be assumed by the presented data. However, during interview some of the respondents responded so negatively that summing up their responses, some comments can be made on the present situation and problems of the SCs of Union Parishad i.e. denying the fact that, "there hasn't been any meeting since my term" was a piece of cake for the presiding member of the committee. Therefore, it is quite impossible to argue against the dysfunctionality of these committees. Each of this committee is so worthless that those can be easily trimmed like the growing fingernails.

A lion's share of those committee personnel do not even have a single clue about the committees they are presiding. As for the other co-opt members, the situation is worse. Most of them have not even been notified by the Parishad that their name has been put on list of committee members. The existence of SCs is nowhere but on papers mostly. However, in some cases not even on black and white. Even though there are some committees on sheets, the formation is completely devoid of any formal procedure.

By the way, residents are absolutely clueless about the idea of SC where the majority of them haven't even heard the term. Therefore, this is supposed to be maintaining the democratic practice at the bottom of the ruling system. After introducing the Union Parishad Act (2009), it has already been ten years since the committees were incorporated in the local governance and yet the efficiency is still highly rhetoric. The inadequate knowledge of the local representatives who are supposed to shoulder these committees is frustrating as hell.

Being out of the reach of any formal law, these committees can offer a colossal platform to take initiatives at the inception of any local affairs more intimately than any other upper bodies. Hence, it can be the special move of the Union Parishad to conserve their influence over their own jurisdiction. Nonetheless, it does not seem to be attracting enough for the concerned bodies. It is a matter of shame that the local governing body is forswearing this super massive opportunity to make themselves more influential. The biggest disappointment is that almost each of them expects to have governments' interference in this regard. In the question of activating the practice of the SCs, governments' continuous guidance is the key as mentioned by the committee Chairmen.

Another very unusual thing about the Union Parishad members is that, most of them can be found daydreaming about being appointed as a government employee who is totally conflicting with the very minimal ethics of politics. It seems like politics as a profession has taken for granted even in the grassroots level since their demand was pretty naked.

The practicality of this survey can be checked by the survey of USAID which was carried out in 3 Union Parishads. The study highlighted on the functions and formation of SC as well as its emergence. The study managed to gather evidence from the field which ensures the effectiveness of SCs practically. By keeping $6 \mathrm{SCs}$ in close inspection it recorded their progress of successes and the issues they have resolved [12]. It was an ambitious effort to show how promising SC can be for the betterment of the local administration. It also proved that proper practices of SC can bring about considerable success in achieving SDG [13].

In terms of challenges of $\mathrm{SC}$, it considered the lack of awareness of the SC members and the overall local government bodies regarding the emergence of SCs [13]. In their words,

"The role and importance of SCs of the local government units were not properly understood by the elected representatives and citizens in the past even though these were officially formed in 2011 after the UP elections. As a result, SCs remained largely ineffective despite the provisions and bindings described in the law."

There is no denying the fact that our local government is highly dependent on the central government in terms of its funds. However, motivations should be gathered by the local representatives for contributing to the overall governance by concealing inclusiveness and democratic values. It is true that $\mathrm{SC}$ is a wonderful tool of decentralization to promote peaceful and inclusive societies for sustainable development, to provide access to justice for all and to build effective, accountable and inclusive institutions at all levels, which are the key focus of SDG 16. Therefore, if the SC is effective and functional, this target can be achieved perfectly without weakening the executive at all [14].

It may be taken for granted that the local government will be the key factor by which multidimensional convenience can be achieved and the service delivery in the local area will be accelerated with proper efficiency. But once and for all, we must focus on building our local governments capable.

Model 1: Inclusive power of standing committee to promote SDG

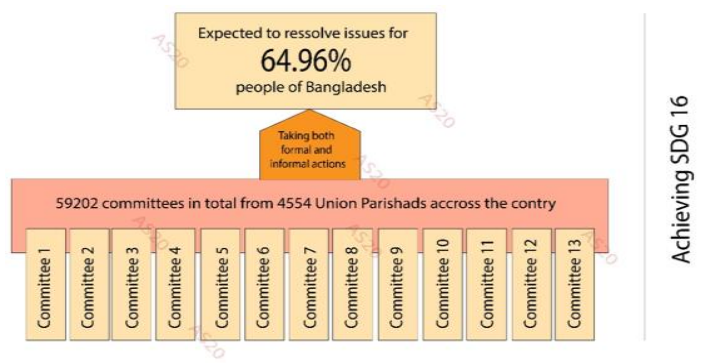

Potentials of standing committees to promote peace, justice and strong institutions 
The Model 1 portrays how the SCs of the Union Parishads of Bangladesh can be one of the handiest tools to assist the country to promote peace and justice along with strengthening institutions through the inclusion of local voice and opinion in the governance tasks. The size of the total population of Bangladesh is 164.7 million [15]. Among them, 64.96\% people [15] reside in rural area which are considerably under the jurisdiction of rural local government bodies like Union Parishad. Since $13 \mathrm{SCs}$ are committed to serve the rural residents of Bangladesh, it can be an enormous possibility to promote peace, justice and strong institutions across the country. On the other hand, SDG is unique since it promises to leave no one behind [2]. Therefore it is one of the crying needs of a country to have a functioning body at the local level to take intimate care of all sorts of local issues.

Model 2: Process of effective functioning of standing committees

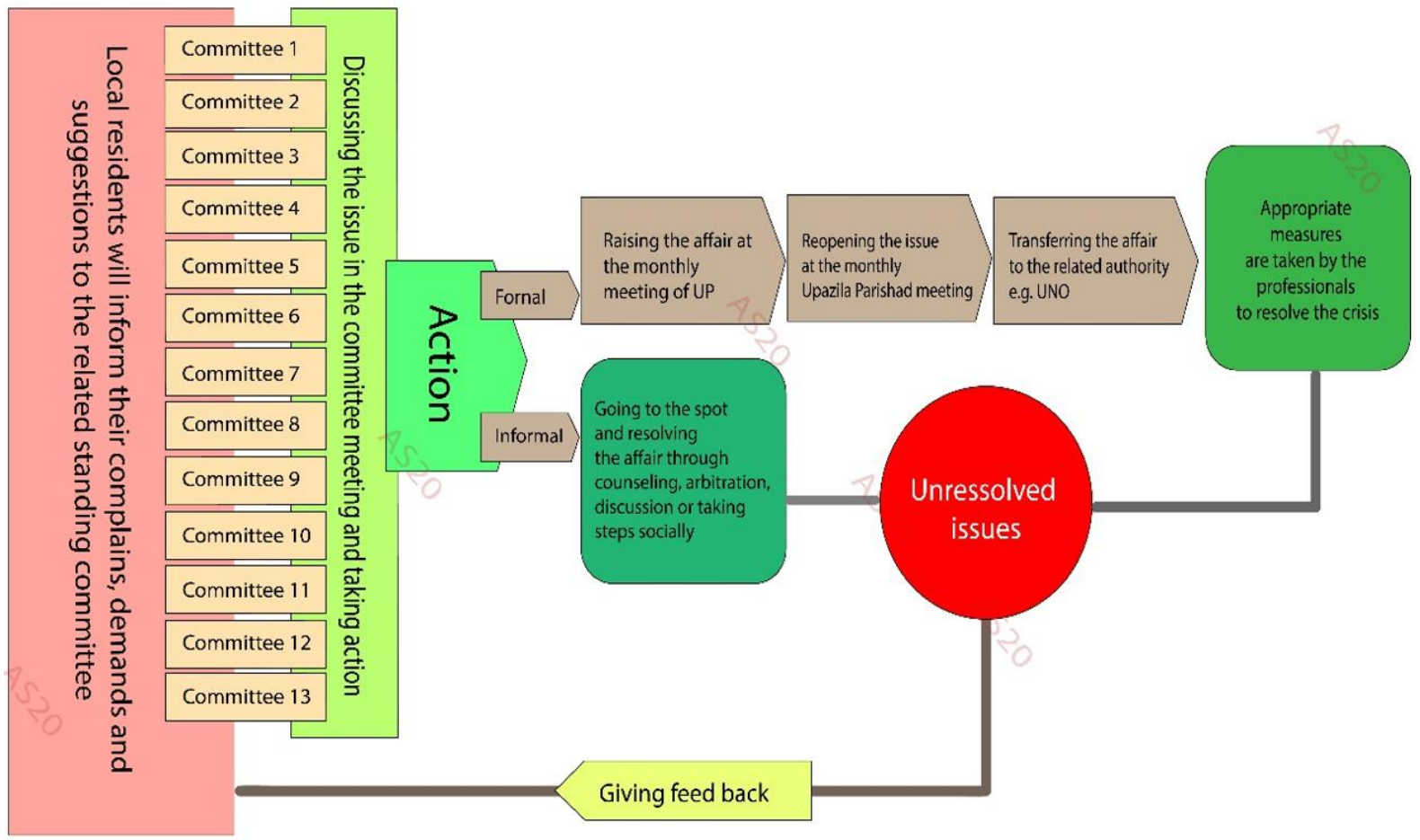

Model 2 can give an idea how Standing Committees can perform accordingly. Following this model SC can ensure the quality of services the local administrations are currently offering [13]. These are as follows,

First, it can resolve on its own initiative the problem in service delivery identified through monitoring.

Second, the SC can report the issue to the UP monthly meeting and the UP chair can place the issue to either Upazila Parishad (UZP) level SC or UZP monthly meeting for appropriate action.

Now, in order to make the local government institutions of Bangladesh the flagship of the SDG 16, the decentralization power and previllage is necessery. Decentralization no doubt plays a key role to ensure active participation in decision making. The plans and policies of our country have always been under question in terms of its democratic quality. For instance, we can blame the century long history of over centralized government. There the dictionary power of the local representatives can transform the decentralization from myth to reality [14]. In fact, decentralization makes our plans and policies more effective and acceptable.

Still in Bangladesh, the idea of decentralization is more rhetoric than reality for various reasons. Among them, the economic insolvency of the local government is a major one. Our local bodies are undeniably a much dependent section. It totally depends on the central government's grant and a tiny amount of taxes which it collects from its area [16].

Nevertheless, there is long list of factors which are responsible for the absence of participation. Among them, the inactiveness of SC is a major one. Since SC offers a chance for the local government to work aside from the central government in the specific territory and includes almost all the local affairs, it has the potential to function as a bridging unit from the most local to most central territory. Although questions can be raised in the capacity of the local representatives, it can generate ideas and keep the local residents up to date at least. But the success lies beneath a strong, dominant, demanding and well-functioning SC.

Finally, the effective and participatory SC has all the credentials to strengthen the local governance and ensure decentralization on the central level indirectly but effectively.

On the other hand, Bangladesh is notorious for the absence of transparency and accountability in almost all of its spheres. Almost all the sectors of this country can be brought under question. The consistent high position in the list of most corrupt country in the world supports this blame. Although it has improved a little over the years, yet it is a continuous concern since all the institutions still need to be strong and effective [17].

The $7^{\text {th }}$ five year plan of our government strictly focuses on the local government of Bangladesh. It has considered the local bodies as a key stakeholder. So it emphasized on the effective and accountable participation. Multiple plans and programs have been initiated all over the country to make the local representatives more strong, active and representative [18]. Part of this venture, UNDP in collaboration with SDC and DANIDA has undertaken a project in 2019 titled Efficient and Accountable Local Governance (EALG) with the aim of strengthening the capacities of local governments (Upazila Parishad and Union Parishad) to foster participatory local 
development. In this project, SC received an extra focus.

SCs have the full potential to inspect the overall functions of the Union Parishad and UZP. It can monitor all the local services and projects through 13 different committees. If each of the committees functions accordingly, every irregularity and lack of transparency can be noticed. Since the UP is responsible to answer to the $\mathrm{SC}$ in black and white, it certainly offers a huge opportunity for the SC to maintain the transparency and accountability of all the local authorities and service providers. Therefore, without further delay the activation of SC should be ensured for the sake of sustainable development of the country.

Model 3: How Standing Committees ensure strong institutions through making institutional decisions more optimized, focused and locally effective

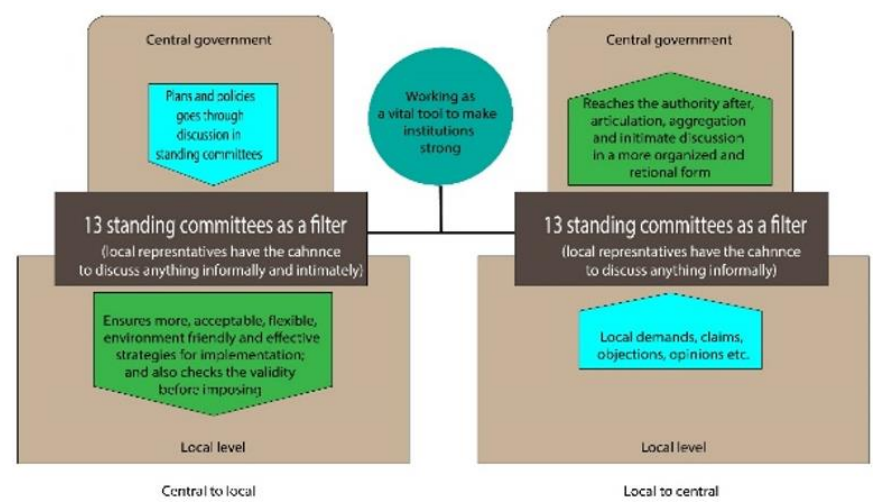

Local government is not just an institution to provide local services, it is more than that. It can offer vibrant facilities e.g. it can be a platform for the local people to practice their civic dialogue. Effective local government can also create a space for the local people to discuss any affair of the government and the $\mathrm{SC}$ is the one to take this under consideration and articulate this to a policy. Since all the affairs goes through scrutiny and intimate discussion by the proper practice of local government and SC, therefore the implementation finally becomes more effective and environmental. However, providing all the local services was never the only objective of the local government. It has the ultimate responsibility to keep the local people under a democratic environment, maintain peace in the area, resolve local disputes, maintain liberty of the residents, and ensure justice in the local level. In this regard, SC is a must to function as a part of the local government [19]. Since, the primary objective of the SDG is to ensure inclusiveness and the SDG 16 is focused to promote peace and strong institutions, the emergence of properly functioning SC must be important. The above model (Model 3) will clarify what SCs have to offer for the sake of local peace and strong local institution.

\section{CONCLUSION AND RECOMMENDATIONS}

As Bangladesh is progressing and reaching nearer to achieve SDGs, the standard of living is also increasing. A standard life generates developed thinking. As the life standard of the people is growing, their awareness is also increasing. A day will come when the rural people of Bangladesh will be aware and more politically socialized. Therefore, undoubtedly, the formation of policies for them will be harder and will require more attention. The task of the government in the future will be huge and heavy if it does not let its local institutions evolve and become matured to reduce the burden.
The central government should reduce its patronization towards local governments allowing them to become matured and responsible for their territory. Research indicates that the local government still keeps a very superficial and inadequate knowledge in all sectors which has appeared as one of the biggest drawbacks in the development of Bangladesh. Various plans, programs and training are initiated by the government and non-government institutions, but the result is not satisfactory. Moreover, stepping to the group of nations with middle income has the threat to increase the responsibilities of the local bodies. Therefore, the capacity of the local institutions will fall short in the near future.

In these circumstances, where achieving the SDGs within 2030 is the biggest priority, the urgency of strengthening the local institutions is therefore more optimum than ever. In this regard, well-functioning SCs can be a solution for every local institution as well as for the government of Bangladesh. If the SCs are patronized, monitored, brought under a formal law, and provided with logistics and training for the committee members, the local government of Bangladesh will no doubt become more inclusive, transparent, accountable and effective. In fact, functions in such order will certainly be fruitful in promoting peace and justice at local level and introducing strong institutions over the country. Thus, sustainable development can be ensured.

\section{ACKNOWLEDGEMENT}

We would like to express our gratitude to the Ministry of Local Government, Rural Development and Cooperatives of the Government of Bangladesh, UNDP Bangladesh, SDC, and DANIDA by whom the research was funded under the project of Efficient and Accountable Local Government (EALG). Besides, our sincere thanks to the Institute of Bangladesh Studies (IBS), University of Rajshahi for supervising and letting us be a part of the EALG project in Rajshahi Region. We are also very grateful to the study participants, the research assistants and the staff of the selected Union Parishads of this research. We are also thankful to the anonymous reviewers of this manuscript. Their constructive feedback has significantly improved the content and presentation of this manuscript.

\section{REFERENCES}

[1] Economic and Social Council (ESC). (2019). Secretary General Report, Progress towards the Sustainable Development Goals, Economic and Social Council (UN). https://undocs.org/E/ 2019/68.

[2] United Nations. (2019). HLPF Review of SDG Implementation. https://sustainable development. un.org/ content/documents/23672BN_SDG16_LV.pdf.

[3] Alamgir, H. (2017). Tekshoy Unnoyan Ovishto [Sustainable Development Goals]. Cabinet Presentation in Bangladesh Statistical Bureau. http://bbs.portal.gov.bd/sites/default/files/files/bbs.porta 1.gov.bd/page/3acbc97e_6ba3_467b_bdb2_cfb3cbbf059 $\mathrm{f} /$ Presentation $\% 20$ on $\% \overline{20}$ SDG $\% 20$ for $\% 20$ Bangla_Alam gir.pdf.

[4] Internal Resources Division (IRD). (2019). Accelerating Growth, Empowering Every Citizen. Bangladesh Government Portal. URL: ird.portal.gov.bd > sites > default $>$ files $>$ files $>$ ird.portal.gov.bd $>$ notices. 
[5] Mohammad, I.T. (2019). Without Decentralization, We Cannot Have Effective Local Government. The Daily Star, Feb 15, 2019. https://www.thedailystar.net/supplements/stronginstitution-good-governance/news/withoutdecentralisation-we-cannot-have-effective-localgovernment-1702108.

[6] Union Parishad Operational Manual. (2013). Structure and Function of Standing Committees. Published by Local Government Division of the Ministry of Local Government, Rural Development and Co-operatives, The Government of the People's Republic of Bangladesh.

[7] New Catholic Encyclopedia (NCE). (2020). Peace in the Bible, Entry of I.G. Gillman. https://www.encyclopedia.com/religion/encyclopediasalmanacs-transcripts-and-maps/peace-bible.

[8] Ilias and Islam. (2014). Effectiveness of Standing Committees: A Study of Seven Union Parishads in Bangladesh. Published in NILG's Research Program Journal 2013-14.

[9] Field Survey (2019). Conducted at Yusufpur, Godagari and Puthia Union of Rajshahi District in Bangladesh from June 4 to June 10, 2019.

[10] Kumar, P.P. (2018). Standing Committees for Effective Local Governance. The Daily Sun (online version), March 12, 2018. http://www.dailysun.com/printversion/detail/295058/2018/03/14/Standin g-Committees-for-Effective-Local-Governance.

[11] Hossain, A. (2017). Functional UP Standing Committees and Perceived Benefits. Published on the Daily Sun. Dated on: December 11, 2017. http://www.dailysun.com/print version/details/274386/Functional-UPStandingCommittees-and-Perceived-Benefits.
[12] Kabir, M., Khan, A.R., Guda, R.S. (2014). Improving Services: The Role of Union Parishad Standing Committees. Theme: Strengthening Democratic Government. Published by Unnayan Shamannay (US), 2014, Dhaka.

[13] USAID. (2014). Strengthening Democratic Local Governance (SDLG) in Bangladesh, Quarterly Progress Performance Report-No. 11 October 2014. https://pdf.usaid.gov/pdf_docs/PA00K8DZ.pdf.

[14] Mohammad, I.T. (2019). Without Decentralization, We Cannot Have Effective Local Government. The Daily Star, Feb 15, 2019. https:/www.thedailystar.net/supplements/stronginstitution-good-governance/news/withoutdecentralisation-we-cannot-have-effective-localgovernment-1702108.

[15] Bangladesh Bureau of Statistics (BBS). (2015). Population Projection of Bangladesh: Dynamics and Trends (2011-2061). Statistics and Informatics Division (SID), Ministry of Planning. Government of the People's Republic of Bangladesh. http://203.112.218.65:8008/WebTestApplication/userfil es/Image/PopMonographs/PopulationProjection.pdf.

[16] Akhter, H. (2018). Decentralization in Bangladesh: Turning Myth into Reality. The Daily Sun on Feb 5, 2018.

[17] Iftekharuzzamn. (2019. Bangladesh Descends in Corruption Ranking. The Daily Star on Jan 30, 2019.

[18] Kumar, G.A. (2018). Quoted in the article of, Strengthening Local Government in Bangladesh. The Daily Independent on Mar 26, 2018.

[19] Bappy, R. (2018). Local Governance in Advancing SDGs: Whither Bangladesh? The Daily Sun on October 30, 2018. 